\title{
Translation and Spreading of Folk Culture: The Case of The Last Quarter of the Moon
}

\author{
Xiaowei Zou* \\ College of Humanities and Social Sciences, Heilongjiang Bayi Agricultural University, Daqing, \\ 163319, China \\ *Corresponding author:
}

Keywords: The Last Quarter of the Moon, folk culture, translation

Abstract: With the deepening of globalization, mutual cultural communication has become a trend. China's comprehensive national strength is constantly increasing and its influence is also expanding. In the process of cultural communication, Chinese folk culture works are gradually favored by western readers and become one of the channels for the west to understand China. The Right Bank of Argun (2005) is the work of Chi zijian, a Chinese female writer who has won many awards. It was translated by American Sinologist Bruce Humes into English, renamed The Last Quarter of the Moon, and finally published in The United Kingdom in 2013. The spread of The Last Quarter of the Moon around the world is conducive to the spread of Chinese culture and plays a positive role. This thesis takes Susan Bassnett's cultural translation theory as the theoretical basis, combines the analysis of related translation strategies, and analyzes the relevant corpora through examples, intensive research on the translation of folk culture in The Last Quarter of the Moon.

Original article, Published date: 2018-11-26

DOI: 10.23977/aetp.2018.21029

ISSN: ISSN 2371-9397 (Print), ISSN 2371-9400 (Online)

https://www.clausiuspress.com/journal/AETP.html

\section{Introduction}

Chinese culture has a several-thousand-year long history, and covers huge varieties. In the Chinese traditional cultural history, the folk culture of ethnic minorities is shining in it and leaving extremely precious spiritual wealth for people. It is also the treasure of worthy of investigation by people generation to cherish. However, with the new era of globalization, China is constantly learning from Western culture, taking its essence, discarding its dross, and also trying to show the 
West the outstanding culture of China, especially the folklore of Chinese minorities culture. The communication and integration of Chinese and foreign cultures has become a trend of cultural integration in the world under the background of globalization. Translation of culture is indispensable. Through the translation, the excellent culture and cultural connotation of the Chinese nation is shown to the world, the mysterious veil of China unveiled, and the world knows China better. The original works, The Right Bank of Argun, describes the ups and downs of the Ewenki people in Northeast China with the ups and downs of Chinese history, which includes all aspects of the Ewenki folk culture. However, translating this kind of literary works with great folklore into other languages is a huge challenge. Chinese and Western cultures have huge differences in all aspects of folklore, and their semantic conflicts and flaws are inevitable. It takes a certain translation strategy to translate at the cultural level, and the difficulty can be imagined. In the translation works, The Last Quarter of the Moon, Bruce Humes skillfully translated into words with Ewenki national culture and Chinese traditional characteristics, spreading the folk culture in the original text to the cultural environment of the target readers, which has important research reference value.

\section{The Right Bank of Argun and The Last Quarter of the Moon}

The Right Bank of the Argun is a novel written by Chinese writer Chi Zijian and won the Mao Dun Literature Award in 2008. Since The Right Bank of Argun was published, the novel has aroused great attention of domestic readers and critics. And it is hailed by the media as one of the most anticipated books. The novel consists of an afterword and four chapters. After reading the novel, the reader can see that the writer Chi Zijian told a story with a self-report of a ninety-year-old, the last chief woman of Ewenki, the protagonist in the book, thus bringing the reader to the story of the Ewenki people life in northeast China. The novel describes the Ewenki ethnic minority in China's northeast's survival condition and several hundred years of history. Chi zijian with exquisite language vividly depicts a group of little-known the Ewenki nationality people with dare love dare hate noble spirit and character. The Right Bank of Argun is the first novel to describe the living conditions of the Ewenki people in the northeast of China and the vicissitudes of the century.

With a sincere and clear heart, Chi Zijian entered the life of the Ewenki people, and poetically told the stubborn persistence and cultural changes of a minority in a tender and lyrical way. This "family" work can be regarded as a frank dialogue between the author and the people of the Ewenki nationality. In the dialogue, she expressed the esteem of the ideal human spirit that is obscured by modernity, such as respect for life, reverence for the forces of nature, persistence in faith, love and hatred, etc. The language is exquisite. The novel is a cultural epic, and is an excellent work with bright style, far-reaching artistic conception, and excellent ideology and artistry.

The English version of the novel was translated by the sinologist Bruce Humes, Chinese name $\mathrm{Xu}$ Mushi and the original name The Right Bank of Argun was renamed to The Last Quarter of the Moon, published in 2013 by Harvill Secker, a subsidiary of Langdon Books in the UK. Since its publication, it has been widely appraised by overseas readers and attracted the attention of literary and translation scholars all over the world. As a successful example of the translation of Chinese ethnic minority cultural works, The Last Quarter of the Moon is of profound significance for the introduction of Chinese folk culture into the world.

Bruce Humes, an American literary translator and literary critic specializing in the English translation of non-Chinese writers and their works. Humes "cultural hybrid" identity has a significant impact on Humes' selecting translation materials, which shows Humes' choice of literature on ethnic minorities and the original work itself. In his translation behavior, Humes achieved the "loyalty" of the translation of national cultural vocabulary by using translation 
methods such as literal translation, transliteration, transliteration plus interpretation, the "authenticity" of syntactic translation and the "comprehensiveness" of textual translation. As a "medium" for cultural dissemination, in the translation of ethnic literature, it is necessary to preserve the characteristics of ethnic culture and enhance the right of national discourse. At the same time, it is necessary to take into account the receptivity of the target language readers to the novel, reasonably translate the text under the principle of cultural translation theory, and promote Chinese national literature to the world.

\section{Cultural Translation Theory and Folk Culture Translation}

\subsection{Cultural Translation Theory}

With the development of cultural translation, people pay more attention to the influence of culture on the quality of translated works, including the cultural background of the target language readers and the cultural background of the original text. Based on the theories proposed by predecessors, Susan Bassnett followed the trend of the times and proposed a theory of cultural translation.

The emergence of cultural translation view shows the "cultural turn" of translation studies. Traditional linguists often only pay attention to equivalence conversion at the linguistic level and ignore cultural factors. However, traditional linguistics cannot well solve the cultural challenges faced by translations in different cultural backgrounds, such as social history, national psychology, thinking methods, etc. Cultural translation concept refers to the translation research in cultural context, which emphasizes the impact and constraint of target cultural context on translation activities.

The traditional linguistic school believes that translation focuses on "reasonableness", that is, when form and meaning cannot coexist, the meaning of the language should be selected, and the approximate target language should be used to express general imagery to achieve functional equivalence. The cultural translation school holds a different view. The linguistic form and content in literary translation cannot be completely separated.

Under the concept of cultural translation, in order to achieve cultural equivalence, the translator must consider the acceptability of readers in different cultural backgrounds and appropriately rewrite the original text language. In the process of rewriting, the translator has a certain creative space, which makes it more in line with the discourse habits and culture of the target language. The translator can combine the local language habits, politics, ideology, culture, gender and age of the audience to rewrite the work to achieve better dissemination of the work. Therefore, each translation is affected by the translator's subjectivity and cultural translation theory.

According to translator Bruce Humes, translating Chinese minority literature is intended to increase China's transparency, break the so-called Chinese mysteries, and allow the outside world to better understand the minorities in China and their culture, literature, and outlook on life. The Right Bank of Argun, published in 2005, describes the rise and fall of the Ewenki people along with the ups and downs of Chinese history, and the generations, honors, and disgrace. It contains all aspects of the Ewenki national life, the moon, the reindeer, the shaman and faith, depicts the cultural change of a minority, so during the translation process, the translator revolves around the translator's subjectivity under the concept of cultural translation, and translates articles, especially in the area of folk culture, using special translation strategies to express the original author's meaning and translate the original. 


\subsection{Folk Culture Translation}

Folk culture, also known as traditional culture, is the general name of people's life culture. It also refers to the customary life habits created, shared, and inherited by people living in a country, nation, or region. A series of non-physical things were formed in the production, folklore and the daily life of the people. Folk culture because of its core elements, folk customs, are collectively followed, repeatedly demonstrated, and constantly implemented, with the function of enhancing national identity, strengthening national spirit, and shaping national character. Folk custom is one of the social ideologies, and also a kind of cultural heritage with a long history.

Folk culture covers a wide range of contents, including production and labor folk customs, daily life folk customs, festival folk customs, life etiquette, folk concepts, folk literature, entertainment folk customs, social organization folk customs, religion and witchcraft, etc. Generally speaking, folk culture can be divided into two aspects: material and spiritual. The spiritual culture includes historical traditions, social customs (funeral, marriage, festival traditions, etiquette and taboos, etc.), folk languages (dialects and common sayings, etc.), folk wisdom (proverbs, etc.), folk literature (poems, songs, stories, legends and dramas), folk arts (dyeing and weaving skills, sculpture, music and dance, etc.), entertainment folk customs (games, and competitions, etc.), calendars, religious spells and beliefs, names (names of people and places). Material folk culture includes buildings, production tools, daily necessities, diet, clothing, family medicine and prescriptions, handicrafts, transportation facilities, etc. As the main support and fundamental source of human survival, material folk culture is closely related to human development and runs through the whole process of human production and practice. (C. S. Burne, 1914; Pierre Santyves, 1936, etc.)

\section{Translation and Spreading of Evenki Folk Culture in The Last Quarter of The Moon}

Evenki is a nationality in northeast Asia. In China, Evenki mainly live in Mongolia and Heilongjiang provinces. In addition, some people live in Siberia, Russia and Mongolia. The Evenki people in different areas were once called "Soren", "Tunguska" and "Yakut" due to the differences in living areas formed by historical migration. Soren used to include not only Evenki, but also Daur and Oroqen. With the gradual separation of other minorities, Soren has become the name of Evenki. The Soren make up the majority of the Evenki population. After the founding of the People's Republic of China, the Chinese government unified the names of "Soren", "Tungus" and "Yakut" as Evenki according to the wishes of the Evenki people.

It is said that as early as 2000 BC, the Evenki ancestors lived in Lake Baikal and the coastal areas of Lake Baikal. According to Evenki legend, their hometown is the Lena River. Shiwei in Northern Wei Dynasty, especially Beishiwei, and Jubu in Tang Dynasty, are closely related to Evenki. According to historical records, Beishiwei's customs of "hunting for a living, eating meat and wearing clothes made of leather, chiseling ice for fishing, building houses with birch bark, and carrying out wind burial" are very consistent with those of the early Evenki. After the Tang Dynasty, the central government successively set up some organizations, such as"Du du fu”, "Jie du shi" and"Wei suo", to administer the Evenki region. Evenki people are united and patriotic. They fought bravely against the enemy and cracked down on the Russian and Japanese invaders heavily in the 17th and 20th centuries respectively.

\subsection{Spiritual Folk Culture of the Evenki Nationality}

Animal husbandry and agriculture are traditional Evenki industries. With the development of industrialization, some urban areas in Evenki have gradually embarked on the road of economic revitalization with diversified development. However, because the Evenki people live in scattered 
places and have different natural conditions, their social and economic development is very uneven. The economy of some remote areas is still lagging behind.

Evenki people generally named their clan "hala" after place names or personal names. The head of the clan is called "Halada". Several clans formed a tribe. Evenki people have a unique Evenki language but do not have their own written characters. Historically, Evenki people have learned to use Manchu. With the development of the times, Evenki people have generally mastered Chinese, Mongolian, Russian and other languages in modern social life.

Evenki like singing. Their folk songs are bold and unconstrained and full of grassland and forest hint. It is characterized by impromptu lyric writing and impromptu feelings from the scene. Evenki people love swans and take swans as totems they worship. Swan dance "Uubchu" is a folk dance of Evenki nationality. They have some folk customs: when they saw the upright charcoal in the morning, it showed that someone was coming today, so they had to bend over and say hello to it, or they would have snubbed the guests. If they see upright charcoal at night, they will knock it down, because it indicates that ghosts are coming. There are also some folk prescriptions for curing diseases, such as smash dried bats into powder to cure the cough of reindeer. The widow drew three circles with her index finger on the child's sore and blew it three times. After nine times, it is easy for a sore to heal.

Most Evenki people believe in Shamanism. Shamanism is a religion based on polytheism and animism. Shamanism has a long history and even is said to have existed in the Stone Age. Shamanism advocates a shaman-centered divine belief. The word "shaman" means someone who knows all things in ancient Evenki. Shamans are powerful, capable of healing, evoking souls, and bringing the dying back to life, etc. However, shaman's Spirit Dance Performance often comes at a price. For example, in the book, shaman Nihau loses a child after every Spirit Dance. Evenki people worship nature and believe in the theory of animism. Evenki people believe that heaven has gods, mountains have gods, fire has gods ... These gods control everything in their respective fields and control people's life and death. People must respect and worship them and protect nature in a reasonable way and with sincere heart. This kind of consciousness is manifested in Evenki people's worship of heaven, sun, moon and stars. Most Evenki people carry out celestial burial (namely wind burial). Evenki people revere the Fire God. They always throw a piece of meat and sprinkle a glass of wine into the fire before drinking or eating meat. When getting married, newly-married couples should toast the Fire God. In addition, Shamanism worships goddesses and women are leaders in social life. This point is reflected in The Last Quarter of the Moon: the heroine in the book is a female chief; the best shaman is a female shaman. The Fire God is an old lady. Shamanism also advocates totem worship and animal worship. Some clans worship birds and bears as totems target. Evenki people believe that human beings and animals are equal. They believe that humans and animals will replace each other in reincarnation. In The Last Quarter of the Moon, the Shaman cured Dana of her illness by offering a little reindeer to the gods, but Dana fell from the mother of the reindeer and froze to death. The female chief lost her daughter because the clansman killed a fawn. The chieftain's mother died and became a snake, so the female chieftain no longer allowed future generations to kill snakes.

\subsection{Material Folk Customs of the Evenki Nationality}

"Evenki" in Evenki language means "people living in the mountains". Evenki people engaged in animal husbandry production and made a living by hunting. For a long time, they adopted the production and life style of "living by water and grass" and gradually developed from nomadism to settlement. Evenki people have a unique Evenki language but do not have their own written characters. Historically, Evenki people have learned to use Manchu. As time goes on, Evenki people 
have generally mastered Chinese, Mongolian, Russian and other languages in modern social life.

Traditional clothing of Evenki is mostly made of leather. They made winter robes, trousers, boots, gloves, socks and other clothing from roe deer skin, deerskin, sheepskin and so on, so as to be suitable for walking on mountains and snow. Reindeer are their only means of transportation. People identify reindeer as the mascot of Evenki nationality. Evenki people regard reindeer as symbols of beauty, happiness and enterprise, as well as symbols of lofty ideals. They all love reindeer very much and want to protect them. At the same time, they built a movable dwelling place called "Shirangju" for living; built kolbo for storing things; and made Ulmuktu Tuluku and ulewung for hunting.

Evenki people have created rich and colorful handicrafts. Evenki women are good at embroidery, carving, paper cutting and other skills, and the patterns are mostly drawn from production and life. Evenki people use birch bark to make tableware, containers, costumes, residences and other things for daily life and sacrificial things such as spirit pictures. They engraved birch bark into various animals and are good at carving beautiful natural patterns such as flowers, plants and animals on vessels. Their birch bark handicraft is called "Mata". Handicrafts convey the beliefs, historical anecdotes and rational thinking of the ancient Evenki people, and contain people's yearning for beauty and pursuit of enterprise.

Evenki people eat dishes made by milk, flour and meat as their daily staple food and like to drink milk tea. Evenki people dry animal meat into meat jerky and strips, and use it as food when they go out for hunting. Evenki traditional tableware also has its own characteristics, such as small wine cups made of antlers, various bowls and dishes made of leather, etc.

\subsection{Translation and Spreading of Evenki Folk Culture}

Translation is a kind of cross-linguistic and cross-cultural communication behavior. The differences of language and culture inevitably lead to the loss of some cultural connotations in translation. Evenki folk culture is presented in all aspects of Evenki people's life, such as clothing, food, transportation, customs and so on, including political words, religious words, belief words, myths and allusions, culture-loaded words and so on. Therefore, Cultural gap will bring some difficulties and challenges to translation. In the process of translation, translators should not only consider the connotation of folk culture words, but also adopt some translation methods and strategies.

Foreignization and domestication translation strategies were put forward by Lawrence Venuti (1994) in The Translator's Invisibility. Foreignization is closer to the target language and allows readers to understand the contents of the original text more easily as much as possible. As for the domestication strategy, the translator should try his best to keep the content and connotation of the original work so that readers can get closer to the original author. In summary, Bruce Humes's English translation of The Last Quarter of the Moon adopts a comprehensive strategy of foreignization and domestication, and successfully pushing the unique Evenki folk culture to the world.

The translator adopts the different translation strategies to translate the original text so as to help English readers to read and understand. The translator, using literal translation method, directly translates some words concerning the material folk culture in the original work to let foreign readers understand the meaning of the book directly. For example, in architecture, the translator translated “三角棚”into " triangular shelter "; in terms of clothing, “羽毛裙子” is translated as " feather skirt " ; in terms of diet, “猴头菇” as " monkey head mushroom " ; in hunting, “猎刀”'is translated as " hunting knife ", and “鹿哨” as " deer-whistle "; in terms of medicinal materials, “狼舌草”is translated as "wolf-tongue grass ", and “廄香”is translated as " Musk". The above translations fully 
illustrate that the translator Bruce Humes not only strives to conform to the readers' acceptance psychology, but also strives to preserve the ethnic characteristics of the Evenki.

Chi Zijian often uses some unique Chinese language forms in her creation, such as common sayings, idioms, proverbs and ancient poems. The Chinese cultural information contained in these characteristic words does not correspond to foreign cultures. In order to successfully realize the transmission of equivalent information, the translator Bruce Humes must consider the acceptability of the English audience, understand its meaning in the Chinese context, paraphrase or explain according to the meaning of the original text, and finally translate it accurately in English. “属相”, also known as the Chinese zodiac, is a word with distinct Chinese characteristics. It is made up of twelve kinds of animals (i.e. mice, cattle, tigers, rabbits, dragons, snakes, horses, sheep, monkeys, chickens, dogs and pigs). These 12 animals, representing the twelve branches of the earth, together with the ten heavenly stems symbolize time. Therefore, zodiac signs are used to symbolize the year of a person's birth. This shows the admiration and love of ancient Chinese for animals. The author of this paper believes that the translator Bruce Humes's translation of "the twelve Earthly Branches" is not accurate enough. Therefore, the author combines transliteration with liberal translation and modifies the translation into "Shu xiang, or twelve Chinese zodiac signs, which are used for symbolizing a person's possible year of birth ".

Because Evenki is not the same as Han nationality, the translator did not transliterate some words with Evenki characteristics in The Last Quarter of the Moon directly according to Chinese pinyin, but adopted a Latin translation strategy, such as translating “我们这个乌力楞只剩下我和安草儿了 (Chi, 2013, p.2).” into " Only An'tsaur and I remain behind in our urireng(Humes, 2013, p.4). ". There are two reasons for adopting this translation strategy: one is that Evenki language does not belong to the Chinese language family, so direct translation in Chinese pinyin is not authentic and not easy; the other is that Latin translation is a special de-familiarization translation strategy, which embodies the particularity of culture.

Evenki people have no fixed residence. "Cuoluozi" is a traditional Evenki residence, which is called "shirangju" in Evenki language. Shirangju is actually a cone-shaped building made of pine poles and is also a very simple tent. As the seasons change, the coverings are different. The translator translated the Evenki residence "希楞柱" into "shirangju" instead of "Camp", "Shelter" or "dwelling" to avoid damaging the exotic atmosphere of the work and bring new feelings to foreign readers.

In addition, the translation of "珠尔干屯" into "Jurgang" enables western readers to make sounds similar to Evenki people. In the translation of hunting tools, the glove "伯力"is translated as" Beri ", the "靠老宝" for storing goods is translated as " kolbo ", and the two different guns "乌 鲁大苦得" and "图鲁克" are translated as " Ulmuktu " and " Tuluku " respectively. In addition to hunting, the pouch of tobacco that Evenki people like very much, called "哈道苦", is translated as "kabtuk (tobacco pouch)". The animal that Evenki worship and love, “堪达帘”, is translated as " kandahang ".

Through this translation strategy, the translator has successfully retained the exotic atmosphere of the original work, allowing western readers to experience the unique and interesting Evenki folk culture.

\section{Conclusion}

With the improvement of China's comprehensive national strength and international status, more and more foreigners are eager to learn more about China. It is not only about China's politics, economy and society, but also its culture. Ethnic minorities have a long history and distinctive 
features. They are an integral part of the Chinese nation and play an irreplaceable role in Chinese culture. Translation and dissemination of Chinese minority culture is an important way to show the charm of Chinese multi-culture. However, there are not many books, reports and other documents describing the history and culture of ethnic minorities, and even fewer translated works. The Last Quarter of the Moon was the only English translation version of the original book, which has a great research value.

Bruce Humes fully adopts literal translation, Latin cultural translation, transliteration, interpretation and other translation methods to realize the "faithfulness" of vocabulary translation, "truthfulness" of syntax translation and "comprehensiveness" of text translation. He integrated multiple translation strategies and creatively combined with Latin translation methods to vividly demonstrate Evenki folk culture to foreign readers. Bruce Humes's translation of the unique Evenki culture in the novel The Last Quarter of the Moon neither conforms to the habits of foreign readers, nor is it completely translated according to the original text, pushing the excellent elements of the Chinese culture to the world and achieving quite good communication effect.

\section{Acknowledgements}

This research was financially supported by A study on Translation Strategies of Beidahuang Cultural Tourism Text (Project No. HNK125B-14-11A) and Ecological Research on Western Network Literature from the Perspective of New Media, Special Project of Provincial Social Science Planning Project (Project No. 14D046).

\section{References}

[1] Baker, M., \& Saldanha, G. (2010). Routledge encyclopedia of translation studies[M]. Shanghai: Shanghai Foreign Language Education Press.

[2] Bassnett, S. (1992). Translation studies[M]. London and New York: Methuen.

[3] Eugene, A. N. (1993). Language, culture, and translating[M]. Shanghai: Shanghai Foreign Language Education Press.

[4] Gentzler, E. (2004). Contemporary translation theories[M]. Shanghai: Shanghai Foreign Language Education Press.

[5] Hatim, B. (1996). Communication across cultures[M]. Shanghai: Shanghai Foreign Language Education Press.

[6] House, J. (2015). Translation as communication across languages and cultures[J]. Abingdon: Taylor and Francis.

[7] Humes, B. (2013). The Last Quarter of the Moon[M]. London: Harvill Secker.

[8] Chi Zijiang. (2013). E Er Gu Na He You An[M]. Beijing: People’s Literature Publishing House.

[9] Burne, C. S. . (1914). The handbook of folklore. Folklore.

[10] Hu Xianlan. (2018). A Study on the English Translation of the Ethnic Culture in E Er Gu Na He You An from the Perspective of Translator's Subjectivity[D]. Zhejiang: Zhejiang University of Finance \& Economics. 